\title{
Understanding the suffering of a patient with an illness: signs, context and strategies ${ }^{1}$
}

\author{
César Hueso Montoro² \\ José Siles González ${ }^{3}$ \\ Manuel Amezcua ${ }^{4}$ \\ Candela Bonill de las Nieves ${ }^{5}$ \\ Sonia Pastor Montero ${ }^{6}$ \\ Miriam Celdrán Mañas ${ }^{7}$
}

The aim of this study is to understand the suffering of a patient with an illness, by using a secondary research method, that is, a qualitative meta-study. The primary data source of the meta-study includes "biographical reports". This project is based on a case study, in which the first-hand experiences of a patient with an illness were collected. The findings of the reports were compiled using the Archivos de la Memoria collection of the Index Foundation (Granada, Spain) and journals specialized in editing these materials. A selection of 20 biographical reports was targeted. The results of the meta-study show that suffering is a multidimensional process within a framework of ambiguous feelings. The suffering involves family and social network participation. Patients develop a range of strategies to overcome the illness. One of the effects is the fear of illness relapse or worsening.

Descriptors: Qualitative Research; Life Change Events; Biography as Topic.

\footnotetext{
${ }^{1}$ Paper extracted from Doctoral Dissertation "El padecimiento de la persona ante la enfermedad. Metaestudio cualitativo a través del relato biográfico" presented to Universidad de Alicante, Spain.

2 PhD, Professor, Departamento de Enfermería, Facultad de Ciencias de la Salud, Universidad de Granada, Spain.

${ }^{3}$ PhD, Full Professor, Escuela Universitaria, Departamento de Enfermería, Universidad de Alicante, Spain.

${ }^{4}$ MSc, Professor, Departamento de Enfermería, Facultad de Ciencias de la Salud, Universidad de Granada, Spain.

${ }^{5}$ PhD, Professor, Departamento de Enfermería, Universidad de Málaga, Spain.

${ }^{6}$ Doctoral Student, Universidad de Alicante, Spain. Hospital de Montilla, Spain.

${ }_{7}$ RN, Specialist. Servicio Andaluz de Salud. Spain.
} 


\title{
Compreendendo o sofrimento humano frente à doença: manifestações, contexto e estratégias
}

O objetivo deste estudo foi compreender a experiência do sofrimento frente à doença, utilizando um método de pesquisa secundário, metaestudo qualitativo. A principal fonte de dados foi o relato biográfico, baseado em estudo de caso que reflete a experiência narrada em primeira pessoa, nesse caso, frente à doença. A localização dos relatos foi feita através de pesquisa nos Arquivos de Memória da Fundação Index e em revistas especializadas na publicação desses materiais. Foram selecionados 20 relatos biográficos. Os resultados do estudo mostram que o sofrimento é um processo multidimensional, caracterizado pela ambiguidade de sentimentos. É fenômeno que envolve a família e a rede social. Os indivíduos doentes desenvolvem diferentes estratégias de enfrentamento e é evidente o medo de recaída ou deterioração.

Descritores: Pesquisa Qualitativa; Acontecimentos que Mudam a Vida; Biografia como Assunto.

\section{Comprendiendo el padecimiento humano ante la enfermedad: manifestaciones, contexto y estrategias}

\begin{abstract}
El propósito de este trabajo es comprender la experiencia del padecimiento ante la enfermedad mediante la utilización de un método de investigación secundaria, un meta estudio cualitativo. La fuente de datos primarios ha sido el relato biográfico, un diseño basado en el estudio de caso que recoge la experiencia en primera persona, en este caso, ante la enfermedad; la localización de relatos se ha hecho a través del fondo Archivos de la Memoria de la Fundación Index y de revistas especializadas en la edición de estos materiales. Se seleccionaron 20 relatos biográficos. Los resultados del meta estudio muestran que el padecimiento es un proceso multidimensional, caracterizado por la ambigüedad de sentimientos. Es un fenómeno que comparte la familia y la red social. Las personas enfermas desarrollan diferentes estrategias de afrontamiento y es manifiesto el miedo a la recaída o el empeoramiento.
\end{abstract}

Descriptores: Investigación Cualitativa; Acontecimientos que Cambian la Vida; Biografía como Asunto.

\section{Introduction}

The scientific evidence current departs from the bursting in of new research methods, based on integration, synthesis and secondary analysis of documents that disseminate primary research results. The incorporation of novel research methods, like qualitative research, allows us to understand human responses towards health or disease situations, which turns it into a source of useful recommendations for clinical practice, which can be addressed through secondary research methods ${ }^{(1)}$. The association between qualitative research and secondary research methods comprises most of the reference framework for this study.

The conceptual elements that are part of the present research axis are suffering and disease, concepts that have been previously revised in scientific literature and published in an earlier paper, as a part of the project that also gave rise to this study ${ }^{(2)}$. From this earlier paper, the concept of disease should be highlighted as a three-dimensional phenomenon: (a) Biological dimension (disease-object), closely related with the mechanic view on disease, based on organically-based abnormality or physical or structural dysfunction; (b) Subjective dimension (disease-subject), which addresses the disease from the emic perspective, i.e. intends to answer the question on how the subject feels, what are his/her experiences, how it affects his/her life and (c) the Symbolic-social dimension, which refers to the meaning society projects on the ill person. Regarding suffering, this is considered as a holistic experience, which covers the process through which the person lives and experiences his/her disease.

This research follows the thematic line of other studies, among which research on experiences involving chronic illnesses like diabetes or hypertension stand out ${ }^{(3-}$ 6), related to oncologic processes ${ }^{(7-12)}$, or studies focusing on patients with acute conditions ${ }^{(13-14)}$.

This research is based on a qualitative meta-study, 
in which patients' narratives were used, presented in the form of biographic reports, a narrative mode based on the premises of Phenomenology. Its goal is to obtain qualitative data on concrete research themes, in this case the disease experience ${ }^{(15)}$. The aim was to describe and understand people's experience of suffering when confronted with a disease or health problem situation. To reach this aim, the following specific objectives were proposed: to identify and characterize manifestation types of suffering; describe the context in which it occurs, at individual, family, social and health care network levels; get to know the physical, emotional and social strategies to manage the suffering and describe its consequences.

\section{Method}

An integrative review with a qualitative approach was developed, specifically a qualitative meta-study. Given the characteristics of this work, it could be classified as a metadata-analysis, as it departs from the selection of homogeneous studies from the theoretical and methodological viewpoint ${ }^{(16-18)}$.

This type of studies involve a sequence of different phases: (a) identification of the theme and research question; (b) establishment of inclusion and exclusion criteria and definition of information to be extracted from the selected studies; (c) evaluation of the studies included in the review; (d) interpretation of the results, presentation of the review or knowledge synthesis. Based on the above, the order of this paper followed these four phases, as described next:

a. The question that guided this review was as follows: ¿What experiences are present in people who suffer from a disease?

b. Biographic reports on the disease experience were used as data sources. Biographic reports ${ }^{(19-20)}$ are a kind of primary qualitative studies, obtained through a researcher's in-depth interview with an informer. Hence, this document collects a narrative on an experience a person has gone through, and expressed in his/her own words. The analysis of the interview reaches a minimal description level, so that the author restricts him/herself to transcribing the interview and organizing the data per thematic category, literally reproducing the informant's narrative. Thus, this narration offers material that can be included in integrative reviews, as significant findings can be extracted from the set of other reports, using qualitative analysis techniques, concerning phenomena addressed in different reports ${ }^{(21)}$. In line with the present paper, similar studies were found in other theme areas(22).
The following inclusion criteria were adopted: on the one hand, biographic reports in the informantsprotagonists narrated an experience of suffering in view of a disease in the first person, excluding reports about mental illnesses or related to body dysmorphic disorders. On the other hand, another inclusion criterion was the informants-protagonists' range of profiles, selecting studies that represented different profiles. Thus, the diversification criteria were: type of illness (distinction between acute and chronic illnesses), age of the informants, gender of the informants and family situation (in the attempt to represent different family responsibility situations: married or living with a fixed partner, with children or not).

Reports were sought and selected in different specific sources that publish this type of materials, mainly the document collection Archivos de la Memoria, issued by the Qualitative Research Laboratory of Fundación Index (http://www.index-f.com/memoria/me_inicio. php), although specialized scientific journals were also consulted, like Index de Enfermería or Cultura de los Cuidados. Information has been collected since 2004.

c. To guarantee the suitability of the selected material, each was examined in detail with the support of a critical reading guide for descriptive qualitative research, adapted for this study ${ }^{(23)}$. After selecting the reports, the original authors were contacted to inform that their work had been included in a metastudy, counting on their participation in the analysis and integration of the results.

d. As commented under section b, given the characteristics of the selected material, the integrative review permits integrating the results through conventional qualitative analysis methods that go beyond the presentation and discussion of the findings from the different references included. To interpret the results, an analysis method was chosen that has been adapted from other authors' proposal ${ }^{(20,24)}$, summarized in six steps. Step 1: Definition of the category map or analysis paradigm: A category system was defined, based on the matrix described for axial coding(25), with a view to analyzing the study phenomenon as a process. The categories included and their corresponding codes were: Manifestations of suffering (types and characteristics); Individual context (perceptions, experiences, feelings); Family context (acknowledged persons in the family context, perceptions, experiences, feelings and interactions in the patient-family relation); Socialprofessional network context (dimensions similar to those of the previous category but related to the 
social-professional network); Professional-health institution network context (dimensions similar to those of the previous category but related to the health institution network); Intervening conditions (physical, emotional or socio-cultural factors conditioning the suffering); Actions/Interactions (physical, emotional or social actions and interactions intervening in the coping process); Consequences (physical, emotional or social effects in the person as a consequence of the suffering and coping process). Step 2. Organization and comprehensive reading of all reports. The part of the report that contains the informant's narrative was separated and this material was coded, using a reference code that consists of the initial " $R$ " and the corresponding number (R13 for example). Comprehensive reading served to prove the validity of the analysis paradigm for the selected reports. Intra-case analysis was performed before the joint analysis of the narratives. Step 3. Second reading to code the reports in the described categories. Step 4. After concluding the previous phase, quantitative content analysis(20) was applied to describe and analyze the weight or volume of the text that described each defined category, so as to direct the discussion of the findings. Step 5. Examine the distinct categories with the assigned narratives, so as to develop concepts and proposals to describe each category, as well as classifications and typologies with a view to a better understanding. Step 6. Interpret and write, presenting the concepts, proposals and typologies that emerged in each category, including verbatim quotations from the reports.

\section{Results and Discussion}

The consultation of the search sources resulted in 36 reports that complied with the first inclusion criterion. After applying the second criterion and critical reading, 20 reports were selected (Figure 1 ).

\begin{tabular}{|c|c|}
\hline Code & Bibliographic reference \\
\hline R01 & $\begin{array}{l}\text { Alarcón Morales, S., (2006) “Como un tren que te arrolla: relato de un trasplantado”. Archivos de la Memoria [on-line]. Número 3, fascículo } \\
\text { 1, Fundación Index. Available from http://www.index-f.com/memoria/3/a0615.php }\end{array}$ \\
\hline R02 & $\begin{array}{l}\text { Arenas González, F.M., (2006) “¿La historia se repite? Vivencias de un trasplantado”. Archivos de la Memoria [on-line]. Número 3, fascículo } \\
\text { 3, Fundación Index. Disponible en http://www.index-f.com/memoria/3/a30610.php }\end{array}$ \\
\hline R03 & $\begin{array}{l}\text { Bellido Vallejo, J.C. (2006). "El paso por una unidad de cuidados intensivos y el regreso a la vida". Archivos de la Memoria [on-line]. } \\
\text { Número } 3 \text {, fascículo } 1 \text {, Fundación Index. Available from http://www.index- f.com/memoria/3/a0613.php }\end{array}$ \\
\hline R04 & $\begin{array}{l}\text { Casals Riera, R., (2001) “La opción de Esteban. Dos testimonios en torno a un mismo padecimiento”. Index de Enfermería [on-line]. Año } \\
\text { X, número 34, pp. 42-47, Fundación Index. Available from http://www.index- f.com/index-enfermeria/34revista/34_articulo_42-47.php }\end{array}$ \\
\hline R05 & $\begin{array}{l}\text { Castillo Franco, A., (2002) “El signo de la complicación. El relato de un paciente en su preoperatorio". Index de Enfermería [on-line]. Año } \\
\mathrm{XI} \text {, número 39, pp. 48-52, Fundación Index. Available from http://www.index- f.com/index-enfermeria/39revista/39_articulo_48-52.php }\end{array}$ \\
\hline R06 & $\begin{array}{l}\text { Fernández Lao, I., (2006). “Un cambio radical. Relato de un tetrapléjico”. Archivos de la Memoria [on-line]. Número 3, fascículo 2, } \\
\text { Fundación Index. Available from http://www.index-f.com/memoria/3/a20603.php }\end{array}$ \\
\hline $\mathrm{R} 07$ & $\begin{array}{l}\text { González Requejo, J., (2005)" Lo importante no es lo que te pasa, sino cómo lo recibes. Pilar y su operación de vesícula". Archivos de la } \\
\text { Memoria [on-line]. Número 2, Fundación Index. Available from http://www.index- f.com/memoria/anuario2/a0505.php }\end{array}$ \\
\hline R08 & Ibáñez Gil, E., (2006) “La recta final de mi vida”. Archivos de la Memoria [on-line]. Número 3, fascículo 4, Fundación Index. Available from \\
\hline R09 & $\begin{array}{l}\text { Lafuente Robles, N., (2006) "Cómo vivir con diabetes: una vida de decisiones". Archivos de la Memoria [on-line]. Número 3, fascículo 1, } \\
\text { Fundación Index. Available from http://www.index-f.com/memoria/3/a0606.php }\end{array}$ \\
\hline $\mathrm{R} 10$ & $\begin{array}{l}\text { Leyva Moral, J.M., (2006) "Del dolor a la pérdida. Relato de un amputado en primera persona". Archivos de la Memoria [on-line]. Número } \\
\text { 3, fascículo 3, Fundación Index. Available from http://www.index- f.com/memoria/3/a30603.php }\end{array}$ \\
\hline R11 & $\begin{array}{l}\text { Luis López, I. y E. Lerena Plaza, (2005) "La defensa del miedo, relato de un paciente con insuficiencia renal crónica". Archivos de la } \\
\text { Memoria [on-line]. Número 2, Fundación Index. Available from http://www.index- f.com/memoria/anuario2/a0504.php }\end{array}$ \\
\hline $\mathrm{R} 12$ & $\begin{array}{l}\text { Medina Cordero, A., (2006) "Hospitalización por hematuria franca. Vivencias de un hombre sencillo" Archivos de la Memoria [on-line]. } \\
\text { Número 3, fascículo 3, Fundación Index. Available from http://www.index- f.com/memoria/3/a30609.php }\end{array}$ \\
\hline $\mathrm{R} 13$ & $\begin{array}{l}\text { Padín López, S., (2006) “Diagnóstico: Linfoma de Hodgkin. Relato de una enfermera. De ser cuidadora a ser cuidada”. Archivos de la } \\
\text { Memoria [on-line]. Número 3, fascículo 1, Fundación Index. Available from http://www.index-f.com/memoria/3/a0607.php }\end{array}$ \\
\hline $\mathrm{R} 14$ & $\begin{array}{l}\text { Pardo Vicastillo, V., (2006) “Una lucha sencilla pero real. La vivencia de un paciente operado de corazón”. Archivos de la Memoria [on-line]. } \\
\text { Número 3, fascículo 3, Fundación Index. Available from http://www.index- f.com/memoria/3/a30600.php }\end{array}$ \\
\hline $\mathrm{R} 15$ & $\begin{array}{l}\text { Ponce González, J.M., (2006) “La diabetes: luces y sombras en el camino. Relato biográfico de una paciente”. Index de Enfermería [on- } \\
\text { line]. Año XV, número 52-53, pp. 59-63, Fundación Index. Available from http://www.index-f.com/index-enfermeria/52-53/5963.php }\end{array}$ \\
\hline $\mathrm{R} 16$ & $\begin{array}{l}\text { Poza Artés, C.M. y F.M. Ortíz Jiménez, (2006) “Mi lucha: relato de un paciente laringectomizado total”. Archivos de la Memoria [on-line]. } \\
\text { Número 3, fascículo 1, Fundación Index. Available from http://www.index- f.com/memoria/3/a0612.php }\end{array}$ \\
\hline $\mathrm{R} 17$ & $\begin{array}{l}\text { Sierra Huerta, R., (2006) "El camino más largo. El calvario de una enfermera-paciente cuando su diagnóstico se resiste". Archivos de la } \\
\text { Memoria [on-line]. Número 3, fascículo 2, Fundación Index. Available from http://www.index-f.com/memoria/3/a20601.php }\end{array}$ \\
\hline $\mathrm{R} 18$ & $\begin{array}{l}\text { Solano Ruiz, C., (2005) "Cáncer de mama, una experiencia personal”. Cultura de los Cuidados [on-line]. Año IX, número 18, pp. 7-10. } \\
\text { Asociación de Historia y Antropología de los Cuidados. Available from http://www.index- f.com/cultura/18/18-7.php }\end{array}$ \\
\hline R19 & $\begin{array}{l}\text { Torres Pérez, L., (2006) “El efecto mariposa. Sobre el padecimiento ante una enfermedad Sistémica”. Archivos de la Memoria [on-line]. } \\
\text { Número 3, fascículo 1, Fundación Index. Available from http://www.index- f.com/memoria/3/a0605.php }\end{array}$ \\
\hline $\mathrm{R} 20$ & $\begin{array}{l}\text { Castro Peraza, M.E. de, (2007) La fibromialgia, en el mejor momento de la vida. Index de Enfermería. Año XVI, número 56, pp. 55-59. } \\
\text { Available from http://www.index-f.com/index-enfermeria/56/6434.php }\end{array}$ \\
\hline
\end{tabular}

Figure 1 - Selection of biographic reports included in the study 
Hueso Montoro C, Siles González J, Amezcua M, Bonill de las Nieves C, Pastor Montero S, Celdrán Mañas M.

\begin{tabular}{|c|c|c|c|c|}
\hline Code & Disease / Health Problem & Gender & Age & Family situation \\
\hline $\mathrm{R} 01$ & Liver disease & Man & 45 & Married, with children \\
\hline $\mathrm{R} 02$ & Liver disease & Man & 45 & Divorced and married second time, with children \\
\hline R03 & Respiratory disease & Man & 55 & Married, with two children \\
\hline R04 & Obliterant arteriopathy & Man & 56 & Married, with children \\
\hline R05 & Coronary heart disease & Man & 47 & Married, with children \\
\hline R06 & Tetraplegia due to motorcycle accident & Man & 26 & Single \\
\hline R07 & Ulcerative colitis & Woman & 79 & Single \\
\hline R08 & Cancer & Woman & 76 & Married, with children \\
\hline R09 & Diabetes Mellitus & Woman & 31 & Fixed partner \\
\hline $\mathrm{R} 10$ & Limb amputation & Man & 63 & Married, with two children \\
\hline R11 & Chronic Kidney Failure & Man & 60 & Married, with children \\
\hline $\mathrm{R} 12$ & Frank hematuria due to bladder tumor & Man & 68 & Married, with children \\
\hline $\mathrm{R} 13$ & Hodgkin's lymphoma & Woman & 32 & Single \\
\hline R14 & Coronary heart failure & Man & 66 & Married, with children \\
\hline $\mathrm{R} 15$ & Diabetes Mellitus & Woman & 37 & Single \\
\hline $\mathrm{R} 16$ & Larynx Cancer & Man & 70 & Married, with children \\
\hline $\mathrm{R} 17$ & Spinal muscle atrophy & Woman & 59 & Single, no children \\
\hline $\mathrm{R} 18$ & Breast Cancer, Paget's Disease & Woman & 35 & Married, with children \\
\hline $\mathrm{R} 19$ & Systemic disease & Man & 39 & Single with fixed partner \\
\hline $\mathrm{R} 20$ & Fibromyalgia & Woman & 50 & Separated, with children \\
\hline
\end{tabular}

Figure 2 - Characteristics of the informants involved in the biographic reports included in the study.

In Figure 2, the characteristics of the informants who were involved the selected reports are displayed, based on the adopted diversification criteria. In summary, in half of the informants, the health problem is an acute disease and, in the other half, a chronic condition. Thirteen informants are men and seven women. Ages range between 26 and 79 years; six informants are under 40 years old and five over 65; most informants, i.e. 11 are between 40 and 65 years of age. The informants' family situation varies.
Regarding quantitative data analysis, $56.20 \%$ of the text (informant's narrative included in the biographic report) was coded. The categories joining most of the coded text are the individual context and the professional context. The least representative categories are the social-professional context and all categories referring to the consequences or effects of the suffering, none of which reached the distribution percentage of $5 \%$ of the coded text volume; in between are the family context, actions and intervening conditions (Figure 3).

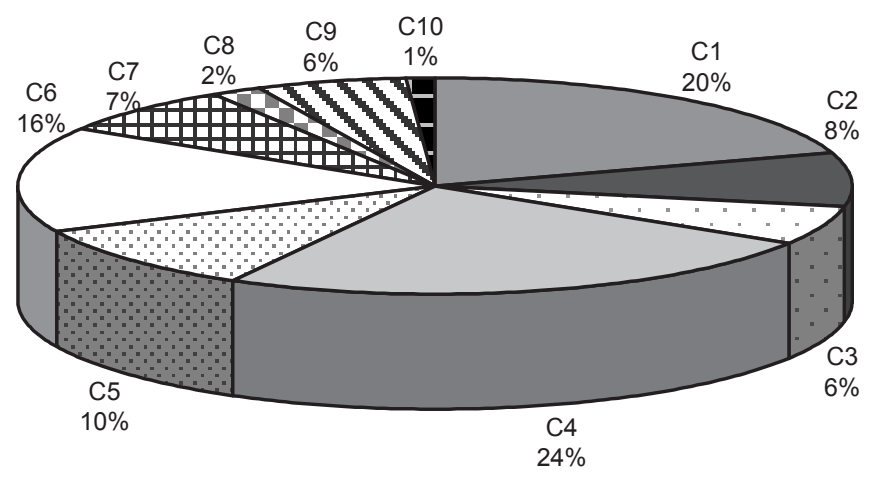

Legend: C: Category

C1. Context - Individual; C2. Context - Family; C3. Context - Social and professional network; C4. Context - Professionals and health institution; C5. Intervening conditions; C6. Actions; C7. Consequences - Individual; C8. Consequences - Family; C9. Consequences - Social and professional network; C10. Consequences - Professionals and health institution.

Figure 3 - Percentage distribution of text per categories in the set of reports included in the study. 
Next, the main findings are presented, deriving from the qualitative integrative analysis of the results found in the selected studies, in line with the previously defined analysis paradigm.

Manifestations of suffering. Suffering is defined as a multidimensional and dynamic process, originating in the sudden or treacherous appearance of a disease or health problem.

The fact is that I hadn't noticed any feeling of disease until the age of 35. Because, of course, as the digestives told me, this disease has a history. (R02)

I had been feeling this chest pain since last summer. The thing is that it was like a kind of tie, and soon I felt a kind of tightening in my arms. (R05)

The disease is accompanied by collateral manifestations like hospitalization, treatment or complications. All of this represents was can be called the suffering management process.

Suffering context. The biased feelings and emotional reactions characterize the informants discourse, in accordance with other studies ${ }^{(11,13,26)}$. In general, patients receive the news of the diagnosis with pessimism, accompanied by skepticism, suffering or anguish.

When that doctor told me "Madam, you have cancer", of course I started to cry. (R08)

A heart problem was detected; can you believe it, me, a man who has worked his whole life, my heart wasn't working. (R14)

¿Things you start to feel from the start? A tremendous threat, a tremendous uncertainty and huge vulnerability (R19)

Emotional reactions involve resignation in some cases and stoicism in others.

Of course living with diabetes every day, sure it's heavy because we've all got good and bad times and, when the bad times come, then you forget about the diabetes and live as you can. (R09)

I suffer, more for them than for me. Sometimes, for example, I have urinated blood, but many days passed before I told it. I have kept back, I suffer and they haven't even noticed. (R12)

One of the categories that emerges in other studies $^{(5,14)}$ to illustrate the feelings the informants perceive is fear, when appears in the treatment context in this study, together with feelings like uncertainty towards what can happen.

$I^{\prime} m$ very scared of the anesthesia, and mainly of not waking up. I'm terrified of that. It's something you can't control, because you don't know what they're going to do nor how it will be. That's what enrages me, that you can't control it. (R07)
The experiences in hospital are another aspect the informants address, particularly events at the Intensive Care Unit (ICU). The ICU is perceived as a solidary place. The high technical level of this environment generates trust and security in the subject, but also some degree of dependence.

And they put you in that room, which I didn't know was the transplantation ICU. They leave you there and you're totally lost, but without losing hope. (R01)

You're afraid of leaving the ICU, because they've practically given you life at the ICU, you believe that the staff won't have proper professional training and you're kind of anguished when leaving (R03)

Some informants' discourse contains significant latent criticism against the health institution's management; this emphasizes that the hospitalization process should be valued, respecting patients' individual characteristics, a situation that puts the excessive specialization and the patient's treatment as an object in check ${ }^{(10)}$.

You realize that the patient often pays the consequences, either due to a lack of staff, lack of expertise or the staff's lack of preparation, which at a given time has to administer a machine or a technology. Those are system flaws. (R03)

The disease experience significantly affects not only the person, but also exerts close influence on the family network. A collective suffering process emerges in which the family and the person suffering constitute a core to cope with the problem, in which the fear, uncertainty and concern with the problem are shared bilaterally. In general, a family member, usually the closest relative (partner, mother) assumes most of the care burden. In some cases, patients consider they put a strain on their family, creating a perceived dependence in the subjects that contributes to enhance their discomfort and changes family relations ${ }^{(13)}$.

It's not funny at all when you're always asking bring me this or that, that they help you wash, get dressed. And, also, you're always thinking that the others suffer, but well, that's life. (R10)

According to other studies(5), the family relation can lead to disintegration or family cohesion. In the reports analyzed, no case of family disintegration was identified, and the increased intensity of family cohesion was highlighted. The family turns into the main physical and emotional therapeutic resource to manage the suffering(26-27).

It's my wife who deals with the treatments. She's responsible for everything. She gives full support, every day, she always comes with me, she's the one who gives me advice. (R11) 
The physical and emotional restrictions that usually come with the suffering not only affect subjects in daily activities, but concretely invade or change their social relations and professional activity ${ }^{(3-5)}$. The social network also plays a central role as a support resource, especially as an emotional agent, which is projected in actions like visiting.

You value the friendship of good times, of those who were there with you, cheering you up and also saying goodbye. (R01)

Even all of the people who come to see you, that's essential for recovery. (R03)

Work and suffering represent a symbiotic conflictive dyad. The disease turns into an invalidating factor that prevents subjects from following their normal work rhythm(12-13); on the other hand, in line with the present findings, work, in turn, is a handicap to be able to effectively manage the suffering, as it presupposes an additional concern.

It wasn't just my disease, but the external pressure I was getting... because all the time they were calling me from the medical inspection, which caused huge tension for me because the medical inspector told me that he would discharge me because the falls had caused many months of sick leave. (R17)

Finally, some reports reveal the informants' clear demand to stay at home. This reveals the importance of health services' awareness-raising and convincing, showing citizens and professionals themselves the advantages of specialized home care, especially in those case in which it can be feasible. The hospital has turned into a kind of totally hermetic disease temple for patients, and that is how they perceive it.

The decision to give me intravenous fluids was mine because, at that time, I considered that the benefits of being at home infinitely surpassed those of a new hospitalization ... I wanted to have the feeling of being at home, also considering friends and visitors, that makes you feel very safe, places you in your reality and helps you to adapt. (R19)

Another analysis level of the social network refers to society's perception of the disease, revealing situations of stigmatization. Nevertheless, when considering nuances, we also found a report (R15) in line with the idea of social acceptance of the disease ${ }^{(7,27)}$.

Sometimes, I sit down on the bus and some people do not want to sit next to me, I've witnessed that an infinite number of times. (R16)

I don't consider myself a sick person, but a disabled person because of the complications, I am aware of my limitations (...) Diabetes is not a disease, because we can do almost everything. (R15)

If something defines the relation between professionals and patients from the latter's perspective, it is trust, in line with other authors' thesis(28), who claim that relations with professionals are based on mutual respect and trust, not only on the technological dependence leading the health system. Despite punctual facts that manifest unpleasant experiences in the way professionals are treated, the general perception is good.

I have never noticed anyone cheating me, I've always felt strong trust in the doctor and the nurse. (R08)

In general, treatment by nursing, physician and subordinated staff has been good. The system functions thanks to great professionals, people working very well and partners who are extremely good professionals. Others leave a great deal to be desired, you can't avoid that, it happens in all groups, we won't solve that, because it can get better, of course. (R03)

Another central element addressed in the reports under analysis is the importance of the information health professionals should provide and share with the subject, to avoid patients' knowledge deficit on their problem(29).

Strategies and intervening factors. The presented results manifest the range of factors influencing suffering. In the disease experience, the analysis of the situation implies an event confined to the biological fact, but which also goes beyond the merely objective, according to the different allusions to the role of religion and God, considering the causes as well as control and healing of the disease(4).

I blame him because that's who you blame. There was a failure there for no matter what reason (...) Nothing divine, things of the body and that's it. That's it and that's what happens. (R05)

I'm a religious man. That has strongly helped me to understand that life does not belong to use, that, for me at least, it belongs to God, for others it will be something else, or genetics. And, as it does not belong to us, it has been decided that we go until here, and here we are. (R01)

Another dimension of interest has been the identification and definition of actions the informants have done to cope with the suffering. The actions found can be classified in three types: actions oriented towards the biological dimension of the disease (taking medication or adhering to therapeutic inertia); actions directed at the subjective dimension (adaptation) or actions oriented at the symbolic-social dimension, like interaction with other subjects in similar circumstances, in line with other studies ${ }^{(4)}$, which positively influences the above dimension.

You adapt to that life and that's it. If you hadn't adapted you'd have jumped off the balcony. (R05) 
At the ward I knew a paraplegic boy. When I was depressed he came to my room with the basketball and started to throw it over the bed. (R06)

The subjects' need for a diagnostic and therapeutic response makes them exhaust all existing possibilities, which is why various professional opinions on their problems are sought or why they look for solutions in alternative therapies, in line with other studies ${ }^{(3)}$.

So the doctor told me that I had to get operated on. And half a year earlier an aunt of mine had been operated on like that, but no, I preferred dying to going through that operation. She got kind of crazy. Well, the doctors laughed but I got treatment from a naturopathic medicine professional then. It went very well. Because all of these years without any problem! (R07)

Some informants' allusion to the use of new information and communication technologies is noteworthy with a view to seeking information.

The information they gave me was very complete. And, well, I got a lot of information from the Internet. The amount of things you get there (...) At least I want to know what they're gonna do to me. Knowing how the process is. (R07)

To cope with the boredom and solitude of hospitalization, the subjects need to get distracted, which is why they develop mechanisms like games and cling to professionals, relatives and friends' company ${ }^{(13)}$.

When I didn't want to get up they put on disco music and made me get up, the porters walked around with me in the chair until cheering me up to leave. When my parents weren't here, they put me in the staff cafeteria with them or in the public cafeteria. (R06)

Consequences. Concerning the consequences or effects of the suffering, this is the least explored dimension; nevertheless, some results should be highlighted and commented on. Hence, the situation of suffering activates an attitude of greater care with preventive and therapeutic aspects of their disease in the subjects, basically out of fear of new relapses or worsening.

$I^{\prime} m$ afraid of a relapse. (R13)

That would concern me, I may have something and the pain does not warn me. I don't feel warned. (R07)

Again, biased reactions towards the new situation are found. While some informants seek alternatives to minimize the presence of the problem, others seem to adherence to the problem in a dependent way, leading to apathy or frustration towards the limits the disease causes.

I've said it often: I'll never accept this, not now, not tomorrow, not in two hundred years, I won't accept it. (R04)
Now I set short-term goals. I'm hoping for my granddaughter's first communion. (R08)

\section{Final Considerations}

Through the integrative review of biographic reports of people with a disease, one can understand the phenomenon of suffering from the perspective of the protagonists, in the first person. On the other hand, the symbiosis between the integrative review and qualitative research methods enhances the production of useful and understandable knowledge for health professionals, who every day have to make decisions in view of the complexity of the human responses that happen in suffering subjects.

Besides the thematic pertinence of additional research in this sense, various aspects are highlighted to further elaborate the method proposed in this research: this study should be continued, especially considering its link with a document collection like Archivos de la Memoria, which includes an average 50 biographic reports on different themes each year, one of which is the disease experience; in fact, periodical reviews of secondary research reports are both verifiable and necessary to evaluate the pertinence of their findings. Finally, it would be interesting to propose studies in the same sense, focused on the experience of concrete illnesses, which would permit a more profound understanding of the study phenomenon in populations that share a same cause or manifestation of suffering.

\section{Conclusions}

In view of the study aims, the main conclusions emerging from this study are as follows:

- Suffering in response to a disease is a multidimensional process that can take different forms (complication, treatment, among others); all of these cause an experience of suffering;

- Biased feelings become evident in suffering subjects. Fear is the characteristic core dimension in individual disease perceptions. Moreover, the family shares the suffering and turns into the main physical and psychological support resource; which is also inherent in the social network. Finally, suffering subjects demand a relation of trust with health professionals and information on their disease process;

- The suffering process entails biological and supernatural connotations, highlighting the role 
of religion as an intervening factor for example. The subjects' actions develop around the triple dimension of their process, among which therapeutic inertia, use of alternative therapies, adaptation mechanisms and interaction with other subjects going through similar processes or circumstances stand out;

- The consequences or effects of the suffering become evident concerning the fear of relapse or worsening and the activation of preventive measures.

\section{References}

1. Nordgren L, Asp M, Fagerberg I. Uso de la evidencia cualitativa en la asistencia clínica. Evid Based Nurs 2008;11(1):4-5.

2. Hueso Montoro C. El padecimiento ante la enfermedad. Un enfoque desde la teoría de la representación social. Index Enferm. 2006;15(55):49-53.

3. Mercado-Martínez FJ, Robles Silva L, Ramos Herrera IM, Moreno Leal N, Alcántara Hernández E. La perspectiva de los sujetos enfermos. Reflexiones sobre pasado, presente y futuro de la experiencia del padecimiento crónico. Cad Saúde Pública. 1999;15(1):179-86.

4. Torres López TM, Sandoval Díaz M, Pando Moreno M. Sangre y azúcar: representaciones sobre la diabetes de los enfermos crónicos en un barrio de Guadalajara, México. Cad Saúde Pública. 2005;21(1):101-10.

5. García García A. Las trayectorias del padecimiento: hombres adultos amputados y no-amputados a causa de la diabetes mellitus. Invest Educ Enferm. 2004;22(2): 28-39.

6. Morse J. Toward a Praxis Theory of Suffering. Adv Nurs Sci. 2001;24(1):47-59.

7. Damião EBC, Pinto CMM. Sendo transformado pela doença: a vivência do adolescente com diabetes. Rev. Latino-Am. Enfermagem. 2007;15(4): 568-74.

8. Torres Pérez V. Mi victoria ante el cáncer. El relato de una paciente que ha superado el cáncer de colon. Index Enferm. 2010;19(1):60-3.

9. Martín Muñoz B, Panduro Jiménez RM, Crespillo Díaz Y, Rojas Suárez L, González Navarro S. El proceso de afrontamiento en personas recientemente ostomizadas. Index Enferm. 2010;19(2-3):115-9.

10. Chubaci RYS, Merighi MAB, Yasumori Y. A mulher japonesa vivenciando o câncer cérvico-uterino: um estudo de caso com abordagem da fenomenologia social. Rev Esc Enferm USP. 2005;39(2):189-94.
11. Maruyama SAT, Zago MMF. O processo de adoecer do portador de colostomia por câncer. Rev. Latino-Am. Enfermagem. 2005;13(2):216-22.

12. Siqueira KM, Barbosa MA, Boemer MR. O vivenciar a situação de ser com câncer: alguns desvelamentos" Rev. Latino-Am. Enfermagem. 2007;15(4):605-11.

13. Solano Ruiz MC, Siles J. Las vivencias del paciente coronario en la unidad de cuidados críticos. Index Enferm. 2005;14(51):29-33.

14. Paiva L, Rossi LA, Costa MCS, Dantas RAS. Experiência do paciente politraumatizado e suas consequências. Rev. Latino-Am. Enfermagem. 2010;18(6):1221-8.

15. Amezcua M. Investigación cualitativa, métodos biográficos e historia oral en el contexto de la salud. Arch Memoria [periódico na internet] 2004 [acesso 8 jan 2011]; 1. Disponivel em http://www.index-f.com/ memoria/anuario1/a0409.php.

16. Gálvez Toro A. Métodos contemporáneos de síntesis científica, una propuesta de homogeneidad. Med Clín. 2003;121(7):256-63.

17. Walsh D, Downe S. Meta-synthesis method for qualitative research: a literature review. J Adv Nurs. 2005;50(2):204-11.

18. Sandelowski M, Docherty S, Emden C. Focus on qualitative methods. Qualitative metasynthesis: issues and techniques. Res Nurs Health. 1997;(20):265-371. 19. Amezcua M, Hueso Montoro C. Cómo elaborar un relato biográfico. Arch Memoria [periódico na Internet]. 2004. [acesso 8 jan 2011]; (1). Disponivel em: http:// www.index-f.com/memoria/metodologia.php.

20. Amezcua M, Hueso Montoro C. Cómo analizar un relato biográfico. Arch Memoria. [periódico na Internet]. 2009. [acesso 8 jan 2011]; 6(33). Disponivel em: http://www.index-f.com/memoria/6/mc30863.php.

21. Hueso Montoro C. Metaestudio cualitativo a través del relato biográfico. Un modelo de investigación secundaria cualitativa. Arch Memoria [periódico na Internet] 2008. [acesso 8 jan 2011]; 5(3). Disponivel em: http://www.index-f.com/memoria/5/ e30801.php. 22. Lorén Guerrero L, Millán Barreiro MP. Vivencias y experiencias de la maternidad. Una revisión de relatos biográficos. Arch Memoria [periódico na Internet]. 2011 [acesso 8 dec 2011]; 8(3). Disponivel em: http:// www.index-f.com/memoria/8/7511.php

23. Gálvez Toro A. Lectura crítica de un estudio cualitativo descriptivo. Index Enferm. 2003;12(4041):51-7.

24. Taylor SJ, Bogdan R. Introducción a los métodos cualitativos de investigación. Barcelona: Paidos Básica; 1987. $343 \mathrm{p}$. 
25. Cassiani SdB, Caliri MHL, Pela NTR. A teoria fundamentada nos dados como abordagem da pesquisa interpretativa. Rev. Latino-Am. Enfermagem. $1996 ; 4(3): 75-88$.

26. Hwang EJ, Kim YH, Jun SS. Lived experience of Korean women suffering from rheumatoid arthritis: a phenomenological approach. Int J Nurs Stud. 2004;41(3):239-46.

27. Moreno C, Sánchez A, Feito MA, Bernat E, Fons AS, Pujol A. Creencias, actitudes y conocimientos de las personas con diabetes tipo 2 respecto a su enfermedad. Enferm Clín. 2004;14(6):307-12.

28. Allué M. Perder la piel. Barcelona: Planeta/Seix Barral; 2000. 236 p.

29. Karasz A, McKee MD, Roybal K. Women's Experiences of Abnormal Cervical Cytology: Illness Representations, Care Processes, and Outcomes. Annals Fam Med. 2003;1:196-202. 